\title{
Microbial pattern of urinary catheterization infection at Wahidin Sudirohusodo Hospital
}

\author{
Muh. Akmal Sukara ${ }^{*}$, Nasir Djide ${ }^{1}$, Nasrum Massi ${ }^{2}$ \\ ${ }^{1}$ Fakultas Farmasi, Universitas Hasanuddin, Makassar, Indonesia. \\ 2 Fakultas Kedokteran, Universitas Hasanuddin, Makassar, Indonesia.
}

DOI: $\underline{\text { https:/ / doi.org/10.29303/sjp.v2i1.47 }}$

\section{Article Info}

Received : 2020-07-31

Revised : 2021-04-18

Accepted: 2021-04-18

\begin{abstract}
Infectious disease still remains a serious problem in Indonesia and worldwide, it leads to use of uncontrollable anti-microbial treatment with cause to drug resistance. With unsupported condition for using a sensitivity test prior to antimicrobial treatment, a common guide for choosing an antimicrobial agent for infection of specific specimen is needed. The aims of this research is to determine the pattern of bacteria, more specific specimen is urine. This research was an experimental consecutive sampling study, sample for this research were taken from ward of Wahidin Sudirohusodo Hospital of Makassar during 2019-2020. The largest number of pathogenic bacteria that potentially becoming infection agent in inpatient room of Wahidin Sudirohusodo Makassar was E. coli. Most of antimicrobial found in range of 61-70 years old, and there was no significant relationship between sex and infections sickness.
\end{abstract}

Keywords: Microbial pattern, urinary infection, catheterization.

Citation: Sukara, M.A., Djide, N., \& Massi, N. (2021). Microbial pattern of urinary catheterization infection at Wahidin Sudirohusodo Hospital. Sasambo Journal of Pharmacy, 2(1), 7-10. doi: https://doi.org/10.29303/sjp.v2i1.47

\section{Introduction}

Infectious diseases still one of the important diseases and become a national problem because they have serious consequences on public health in Indonesia. Infectious diseases need to be handled carefully. Diseases caused by infections have spent enormous funds to control and overcome it. In addition, it has also caused death as many as 13 million people worldwide every year, especially in developing countries like Indonesia. This large death rate can be prevented if a diagnosis is made quickly and precisely and is supported by the provision of appropriate drugs (Susiati, 2008).

Post-invasive patients have a susceptibility to secondary infections. It makes inpatient room contributes to the emergence of antibiotic resistance and the spread of infection by bacterial resistant (Harniza, 2009).

Urinary tract infection is a major source of disease with an estimated 150 million patients per year worldwide and costs the world economy more than 6 billion dollars. The prevalence of elderly patient at ranges from 15 to $60 \%$, and the ratio between women and men is 3 to 1 . The prevalence of young to young adult women is less than $5 \%$ and men less than $0.1 \%$. (Karjono, 2009).

Nowday, the latest data is still needed regarding the pattern of bacterial that cause infection in hospitals, especially for certain specimens and sources of transmission that have the potential to cause infection in Wahidin Sudirohusodo Makassar hospital, therefore this study was conducted to determine patterns of bacteria that have the potential to cause infection in urine samples of patient at inpatients room of Wahidin Sudirohusodo Makassar hospital.

\section{Materials and Methods}

This study is an observational Experimental consecutive sampling study. The study protocol was performed in accordance to institutional human 
research ethical protocols (Nomor: 1040/UN4.6.4.5.31/PP36/2019. Patient's data was collected after patients have got a brief explanation about the study and have signed an informed consent for obtaining urin samples.

\section{a. Patient Criteria}

Inclusion: Male/Female $>12$ years old, fever $>38^{\circ} \mathrm{C}$, Catheterization, urine colony $\geq 10^{5} \mathrm{CFU} / \mathrm{ml}$

Exclusion: pregnant woman, baby and child $<12$ years old

b. Sample Preparation

Urine samples taken from patients with Catheterization infections at Wahidin Hospital Makassar, $30 \mathrm{ml}$ of urine sample is stored in a $100 \mathrm{ml}$ dry sterile bottle, then immediately taken to the laboratory for the process of isolating pathogenic bacteria or stored in a cooler temperature of $40 \mathrm{C}$ for preservation for a maximum of 24 hours.

c. Isolation and bacterial identification

Isolation of pathogenic bacteria in urine samples was carried out using the scratch method on CLED medium (cysteine, lactose, and electrolyte-deficient) then incubated for 18-24 hours at a temperature of $35-37^{\circ}$ C. After the incubation period, bacterial colonies were observed on the surface medium, and then repeat the steps above once more to ensure bacterial growth, if a growing colony $>10^{5} \mathrm{CFU}$ it will be continue for the process of bacterial identification.

Characterization of bacterial isolates was carried out by gram staining method. Its morphology, motility and biochemical characterization carried out with a VITEK 2 compact instrument to identify species.

\section{Result and Discussion}

Table 1. Subject distribution and frequency by age

\begin{tabular}{ccc}
\hline Age (Year) & Amount & Percentage (\%) \\
\hline $12-20$ & 2 & 8 \\
$20-30$ & 2 & 8 \\
$31-40$ & 3 & 12 \\
$41-50$ & 4 & 16 \\
$51-60$ & 4 & 16 \\
$61-70$ & 8 & 32 \\
$71-80$ & 2 & 8 \\
\hline Total & 25 & 100
\end{tabular}

Based on the frequency distribution of patients with catheterization infections against the age groups listed in the table 1 , data obtained between $12-20$ years age group were 2 persons with a percentage of $8 \%, 20$ 30 years were 2 persons with a percentage of $8 \%, 31-40$ were 3 persons with a percentage of $12 \%$, 41-50 were 4 persons with a percentage of $16 \%, 50-60$ were 4 persons with a percentage of $16 \%, 61-70$ were 8 persons with a percentage of $32 \%$, and group age of $71-80$ were 2 persons with a percentage of $8 \%$.

From the results of the frequency distribution of patients with catheterization infections in the age group, in this study showed that aged between 61-70 years were the most frequent incident of infectious which in line with the theory by Smeltzer and Bare, stated the age of patients over 55 years at risk of infection in the urinary tract, due to a decrease in immune system. This characterized by decreased thymus cell atrophy function. Thymus cell involution causes the number and quality of $\mathrm{T}$ cell responses to decrease. The number of memory $\mathrm{T}$ cells increases but is increasingly difficult to develop, especially cytotoxic T cells $(\mathrm{CD} 8+)$ and Th1 cells $(\mathrm{CD} 4+)$ due to apoptosis. Cytotoxic $\mathrm{T}$ cells $(\mathrm{CD} 8+)$ play a role in the immune response to antigens in infected cells by killing infected cells to prevent the spread of infection, while Th1 cells (CD4) play a role in helping $\mathrm{B}$ cells to produce antibodies (Bratawidjaja and Rengganis, 2009).

The results of this study are also in line with research conducted by Kasmad (2007), which explains that age 55 years is an age that is susceptible to urinary tract infections. Another study conducted by Al-Hazmi (2015) states that 15 subjects out of 65 patients $(23 \%)$ by aged 32-54 year is experience urinary tract infections, also 40 subjects out of 97 patients (41\%) by aged 55-62 years experienced urinary tract infections and 45 subjects out of 88 patients $(51.8 \%)$ with age over 62 years had urinary tract infections. The risk of patients with old age is 1.4 times to experience urinary tract infections compared with young patients.

Table 2. Distribution and subject amount by sex

\begin{tabular}{ccc}
\hline \multirow{2}{*}{ Sex } & \multicolumn{2}{c}{ Distribution } \\
\cline { 2 - 3 } & Amount & Percentage (\%) \\
\hline Male & 12 & 48 \\
Female & 13 & 52 \\
\hline Total & $\mathbf{2 5}$ & $\mathbf{1 0 0}$ \\
\hline
\end{tabular}

Distribution and number of subjects in patients with catheterization infection by sex according inclusion criteria were 12 men and 13 women, with percentage of $48 \%$ male and $52 \%$ female (Table 2). The results of distribution of the characteristics of the subjects according to sex, from 25 research subjects obtained the number of female subjects suffering from urinary tract catheterization infections more than male subjects, this result is in accordance with research conducted by Samirah 2004 at Wahidin Sudirohusodo Makassar Hospital stated that from 99 patients with urinary tract infections, the female subjects is the most frequent subject because in terms of anatomy, women is more often infected because the female urethra is shorter than men resulting in contaminant bacteria easily reach the bladder. Another factor is due to the 
tendency of women to hold urine more often and it make an irritation of the urethra, although it rarely occurs in men, but in contrast to the study conducted by Rashella, 2012 at Awal Bros Bekasi Hospital which stated there was no significant relationship between sex and home infections sickness (valve 0.304) but note that invasive action taken will increase the risk 2.3 times to cause hospital infections.

In men, the antibacterial activity contained in prostate secretion to protect the urethra and bladder from bacterial colonization, its function decreases with aging, whereas in elder women the urethral epithelium experiences atrophy due to the aging process which results in a decrease in the strength of urine emission so that the effective removal of bacteria through the bladder has decreased (Smeltzer and Bare, 2008).

Table 3. Bacterial identified

\begin{tabular}{lcc}
\hline Bacterial & Amount & Percentage (\%) \\
\hline Escherichia coli & 19 & 76 \\
Klebsiella pneumoniae & 2 & 8 \\
Pseudomonas aeruginosa & 2 & 8 \\
Staphylococcus aureus & 1 & 4 \\
Acinetobacter baumannii & 1 & 4 \\
\hline \multicolumn{1}{c}{ Total } & $\mathbf{2 5}$ & $\mathbf{1 0 0}$ \\
\hline
\end{tabular}

Based on the results of isolation and identification of bacteria using the Vitek 2 Compact ${ }^{\circledR}$ instrument, showed bacterial growth was Escherichia coli, Klebsiella pneumoniae, Pseudomonas aeruginosa, Acinetobacter baumannii, and Staphylococcus aureus (Table $3)$. This shows that the bacteria that grow mostly are gram-negative bacteria. The most dominant types of bacteria are Escherichia coli which is $76 \%$ found in 19 subjects from 25 subjects that already checked, Klebsiella pneumoniae and Pseudomonas Aeruginosa showed 8\% that found in 2 subjects, then Acinetobacter baumannii and Staphylococcus 4\% each that found in 1 subject.

The results of this study which has been done at Wahidin Sudirohusodo Hospital in Makassar, it was found that the most bacterial that caused the infection of catheterization were Escherichia coli $(76 \%)$. There is no different from the results of study that found by Dini Surya Pratiwi (Dini, 2013) in 2013 at RSUP Fatmawati which stated that the most common bacteria was found in 106 samples diagnosed with urinary tract infections was Escherichia coli (58.5\%). The same study was also carried out by Rostina (Rostina, 2009) in the Clinical Pathology Laboratory of Wahidin Sudirohusodo Makassar who stated that the most bacteria that produce infections in the urine are Escherichia coli. It may occur because the Escherichia coli bacterium is a normal flora, produce benefit colisin for intestine but also pathogenic and may cause urinary tract infections (Broker, 2009).

\section{Conclusion}

Based on the results obtained, it can be concluded that the pattern of pathogenic bacterial that have the potential to cause urinary catheterization infection in the treatment room of Wahidin Sudirohusodo Hospital is Escherichia coli, which is 76\% found in 19 subjects out of 25 subjects, then Klebsiella pneumoniae and $P$. aeruginosa $8 \%$ each, found in 2 subjects, then Acinetobacter baumannii and Staphylococcus $4 \%$ each in 1 subject.

\section{References}

Al-Hazmi, H. (2015) 'Role of duration of catheterization and length of hospital stay on the rate of catheterrelated hospital-acquired urinary tract infections', Research and Reports in Urology, 7, pp. 41-47. doi : 10.2147/RRU.S75419.

Baratawidjaja, KG dan Rengganis, I. (2009). Imunologi dasar. Jakarta: FKUI

Broker, C., \& Gould, D. (2009). Mikrobiologi Terapan untuk Perawat. Jakarta: EGC.

Dini (2013). Kajian Uji Resistensi dan Sensitivitas Antibiotik Ceftriaxone dan Ciprofloxacin pada Penderita ISK di RSUP Fatmawati, Fakultas ilmu kesehatan syaraf hidayatullah, Jakarta.

Harniza, Y. 2009. Pola Resistensi Bakteri yang Diisolasi dari Bangsal Bedah Rumah Sakit Umum Pusat Nasional Cipto Mangunkusumo pada tahun 20032006, Jakarta: Fakultas Kedokteran Universitas Indonesia

Kasmad, Untung Sujianto, dan Wahyu Hidayati. 2007. Hubungan antara Kualitas Perawatan Kateter dengan Kejadian Infeksi Nosocomial Saluran Kemih. Fakultas Kedokteran Universitas Diponegoro, vol. 1, no. 1, hal. 5-6.

Rashella, gita. 2012. Gambaran Epidemiologi dan faktor faktor yang mempengaruhi kejadian infeksi rumah sakit pasca tindakan invasive di Rs Awal Bros Bekasi. Universitas Indonesia, Jakarta.

Rostina, dkk. 2009. Pola Kuman Berdasarkan Spesimen. Indonesian Journal of Clinical Pathology and Medical Laboratory, Vol. 13, No. 1, Nov. 2006: 1316.

Smeltzer, SC dan Bare, BG.2008. Text book of MedicalSurgical Nursing, $8^{\text {th }}$ ed, Philadelpia: Lippincott Williams \& Wilkins. 
Samirah, Darwati, Windarwati, dan hardjoeno. 2006.

Pola dan Sensitivitas Kuman di Penderita Infeksi

Saluran Jurnal Ilmu Kedokteran Dan Kesehatan, Volume 4, Nomor 4, Oktober 2017224 Kemih. Indonesian Journal of Clinical Pathology and Medical Laboratory: 12; 110- 113.

Susiati M. 2008. Keterampilan dasar keperawatan paket 1. Jakarta. Erlangga. 